\title{
The Monomeric G-Proteins Rac1 and/or Cdc42 Are Required for the Inhibition of Voltage-Dependent Calcium Current by Bradykinin
}

\author{
Malgorzata A. Wilk-Blaszczak, William D. Singer, Timothy Quill, Billy Miller, Jeffrey A. Frost, \\ Paul C. Sternweis, and Francesco Belardetti \\ Department of Pharmacology, University of Texas Southwestern Medical Center, Dallas, Texas 75235
}

\begin{abstract}
Although regulation of voltage-dependent calcium current $\left(I_{\mathrm{Ca}, \mathrm{V}}\right)$ by neurotransmitters is a ubiquitous mechanism among nerve cells, the signaling pathways involved are not well understood. We have determined previously that in a neuroblastomaglioma hybrid cell line (NG108-15), the heterotrimeric G-protein $\mathrm{G}_{13}$ mediates the inhibition of $I_{\mathrm{Ca}, \mathrm{V}}$ produced by bradykinin (BK) via an unknown mechanism. Various reports indicate that $\mathrm{G}_{13}$ can couple to RhoA, Rac1, and Cdc42, which are closely related members of the Rho family of monomeric G-proteins. We have investigated their role as signaling intermediates in the pathway used by BK to inhibit $I_{\mathrm{Ca}, \mathrm{v}}$. Using immunoblot analysis and the PCR, we found evidence that RhoA, Rac1, and Cdc42 all are expressed in NG108-15 cells. Intracellularly perfused recombinant Rho-GDI (an inhibitor of guanine nucleotide ex-
\end{abstract}

change specific for the Rho family) attenuated the inhibition of $I_{\mathrm{Ca}, \mathrm{V}}$ by BK. These findings indicate that activation of RhoA, Rac1, or Cdc42 may be required for the response to BK. To determine whether any of these monomeric G-proteins mediate the response to BK, we have intracellularly applied blocking antibodies specific for each of the candidate proteins. Only the anti-Rac1 antibody blocked the response to BK. In parallel experiments, peptides corresponding to the $\mathrm{C}$-terminal regions of Rac1 and Cdc42 blocked the same response. These data indicate a novel functional contribution of Rac1 and possibly also of Cdc42 to the inhibition of $I_{\mathrm{Ca}, \mathrm{V}}$ by neurotransmitters.

Key words: G-proteins; calcium channels; neuropeptides; modulation; neuroblastoma-glioma; NG108-15; Rac1; Cdc42; $G_{13}$
The voltage-dependent calcium current $\left(I_{\mathrm{Ca}, \mathrm{V}}\right)$ occupies a nodal position in neuronal communication, because it couples membrane depolarization to secretion of synaptic vesicles. The critical regulatory role of $I_{\mathrm{Ca}, \mathrm{V}}$ is enhanced by the ubiquitous modulation of this current by a multitude of transmitter receptors (Tsien et al., 1991; Hille, 1992, 1994; Hescheler and Schultz, 1993; Hofmann et al., 1994). Although in most cases, these transmitter actions are mediated via heterotrimeric G-proteins (Hepler and Gilman, 1992; Hamm and Gilchrist, 1996; Neer and Smith, 1996), the downstream signal transduction pathways leading to regulation of $I_{\mathrm{Ca}, \mathrm{V}}$ often do not use the conventional second messengers (Hille, 1994). One signaling mechanism that might contribute to modulation of $I_{\mathrm{Ca}, \mathrm{V}}$ by neurotransmitters involves sequential activation of heterotrimeric and monomeric G-proteins (Bourne et al., 1990, 1991). Activation of monomeric G-proteins would then provide the link for the recruitment of specific mitogen-activated protein kinase (MAPK) pathways (Hille, 1994; Cano and Mahadevan, 1995; Cobb and Goldsmith, 1995; Hunter, 1995; Bokoch, 1996; Kyriakis and Avruch, 1996).

Monomeric G-proteins coupled to MAPK pathways mediate many of the actions of growth factors in a variety of undifferentiated or transformed cells. Receptors for growth factors do not couple to heterotrimeric G-proteins for downstream signaling.

Received Dec. 16, 1996; revised Feb. 24, 1997; accepted March 20, 1997.

This work was supported by National Institutes of Health Grants R01 GM47721 (F.B.), R01 GM31954 (P.C.S.), and R01 GM53032 (M.C.). We are indebted to G Bokoch for the GST-Rho-GDI cDNA construct, B. Hamprecht for NG108-15 cells, M. Cobb for invaluable critical suggestions and the anti- Rac2 antibody, L. Doolittle for sequencing Rac, and $\mathrm{K}$. Edwards for patient and impeccable secretarial assistance.

Correspondence should be addressed to Dr. Wilk-Blaszczak, 5323 Harry Hines Boulevard, Dallas, TX 75235.

Copyright (C) 1997 Society for Neuroscience $0270-6474 / 97 / 174094-07 \$ 05.00 / 0$
Rather, they use tyrosine phosphorylation to initiate a chain of events leading to recruitment of monomeric G-proteins (Cobb and Goldsmith, 1995; Kyriakis and Avruch, 1996). The ensuing activation of MAPK pathways has a long-lasting impact on cellular proliferation and differentiation. Recent studies have enriched this scheme in various ways. For example, neurotransmitter receptors coupled to heterotrimeric G-proteins have been found to contribute to the activation of monomeric G-proteins (Cobb and Goldsmith, 1995; Bokoch, 1996; Kyriakis and Avruch, 1996), leading to downstream actions with speed comparable to that of conventional second messengers (Zhong, 1995; Hooley et al., 1996). In addition, monomeric G-proteins coupled to MAPK pathways have also been reported to play signaling roles in differentiated cells (Cobb and Goldsmith, 1995; Kyriakis and Avruch, 1996).

Using the NG108-15 neuronal cell line as a model system (Hamprecht et al., 1985), we have tested the hypothesis that monomeric G-proteins contribute to the regulation of $I_{\mathrm{Ca}, \mathrm{V}}$ by transmitters. In these cells, bradykinin (BK) and Leu-Enkephalin (Leu-Enk) inhibit the $\omega$-conotoxin-sensitive component of $I_{\mathrm{Ca}, \mathrm{V}}$ via the heterotrimeric G-proteins $\mathrm{G}_{13}$ and $\mathrm{G}_{\mathrm{oA}}$, respectively (Tsunoo et al., 1986; Hescheler et al., 1987; Brown and Higashida, 1988; Shimahara et al., 1990; Taussig et al., 1992; Wilk-Blaszczak et al., 1994b). $G_{\mathrm{oA}}$ produces a fast inhibition, presumably by direct action on the channel (Hille, 1994), whereas $\mathrm{G}_{13}$ inhibits $I_{\mathrm{Ca}, \mathrm{V}}$ slowly, possibly because of a multistep pathway (Wilk-Blaszczak et al., 1994b). Three members of the Rho family of monomeric G-proteins (Hall, 1994; Nobes and Hall, 1994; Mackay et al., 1995; Vojtek and Cooper, 1995; Ridley, 1996), Rac1, Cdc42, and RhoA, have been reported previously to be activated by $\mathrm{G}_{13}$ (Buhl et al., 1995; Collins et al., 1996; Hooley et al., 1996). Here, we present 

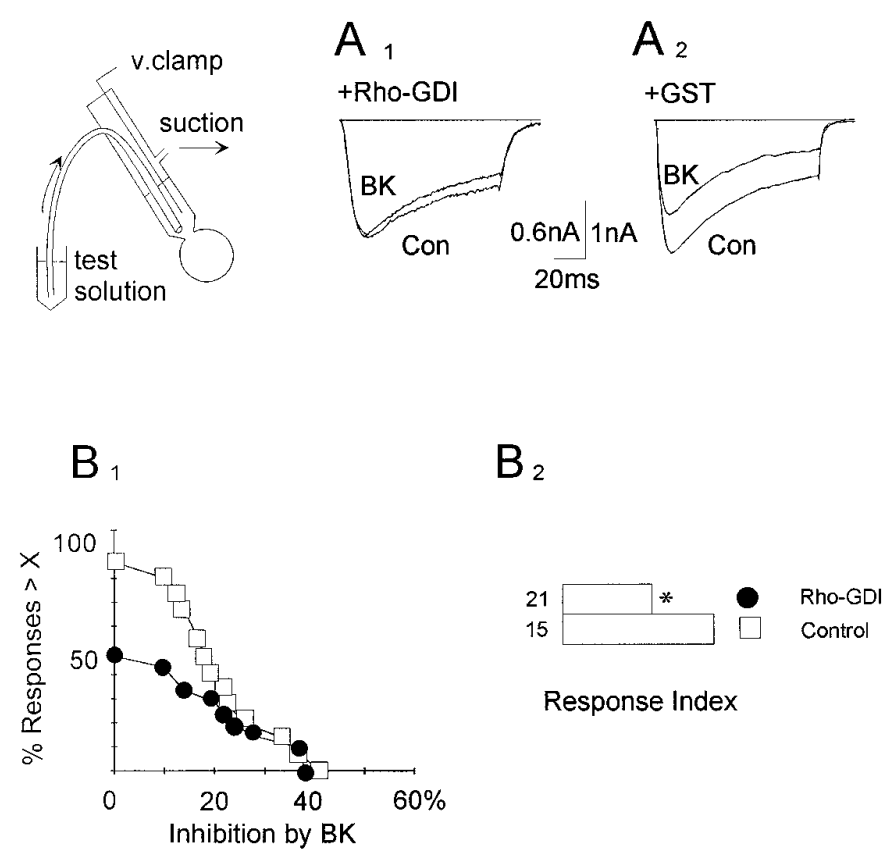

Figure 1. Rho family proteins are involved in the inhibition of $I_{\mathrm{Ca}, \mathrm{V}}$ by BK. $A_{1}, A_{2}$, Responses to $\mathrm{BK}$ either in a cell after a 20 min perfusion with GST-tagged Rho-GDI $\left(0.2 \mu \mathrm{M} ; A_{1}\right)$ or a cell perfused with GST alone $(0.2$ $\left.\mu \mathrm{M} ; A_{2}\right)$. The $I_{\mathrm{Ca}, \mathrm{V}}$ was activated by a $100 \mathrm{msec}$ test command to $0 \mathrm{mV}$ applied every 10 sec from a holding potential of $-90 \mathrm{mV}$ (sampling, 10 $\mathrm{kHz}$ ). Leakage- and capacitance-subtracted current traces are displayed, showing $I_{\mathrm{Ca}, \mathrm{V}}$ before $(C o n)$ and at the peak of action by BK $(0.1 \mu \mathrm{M})$. The continuous line marks the zero current, and the inset outlines the experimental set-up for intracellular perfusion. $B_{1}, B_{2}$, Cumulative distributions of the responses to $\mathrm{BK}\left(0.1 \mu \mathrm{M} ; B_{I}\right)$ and corresponding response indices $\left(B_{2}\right)$ in cells that have been perfused with Rho-GDI (solid circles) or control solution (open squares). The cumulative distributions were constructed as follows. For each cell, the response to BK was expressed as percentage inhibition of the $I_{\mathrm{Ca}, \mathrm{V}}$ before transmitter, and this value $(\mathrm{X})$ was plotted on the horizontal axis. For each $\mathrm{X}$, the fraction of responses (\% Responses $>\mathrm{X}$ ) larger than a given $\mathrm{X}$ was calculated and used to build the cumulative distribution. For example, the cumulative distribution in $B_{I}$ shows that $\sim 90 \%$ of the control cells had a response to BK greater than zero (open squares), whereas only $\sim 50 \%$ of the Rho-GDI-treated cells had a response greater than zero (solid circles). The responses indices $\left(B_{2}\right)$ are proportional to the areas under the corresponding cumulative distribution. The asterisk denotes $p<0.02$, compared with control values, whereas numbers indicate how many experiments were performed for each group.

evidence indicating that Rac1, and possibly also Cdc42, serve as intermediates in the inhibitory pathway between $\mathrm{G}_{13}$ and $I_{\mathrm{Ca}, \mathrm{V}}$.

\section{MATERIALS AND METHODS}

Cultures of NG108-15 cells (passages 15-28) were prepared as described (Hamprecht et al., 1985; Wilk-Blaszczak et al., 1994b). Ciprofloxacin (10 $\mathrm{mg} / \mathrm{l}$, Miles, Kankakee, IL) was added to newly thawed cells for 2 weeks to eliminate potential contamination by Mycoplasma (Schmitt et al., 1988). Intrapipette perfusion (Fig. 1, inset) and electrical recording techniques were used as described previously (Hamill et al., 1981; Tang et al., 1990; Wilk-Blaszczak et al., 1994b). Here are the key points of the procedures used.

Intrapipette perfusion and transmitter application. The effectiveness of the intrapipette perfusion method for delivering reagents in the cells was assessed based on the work of Pusch and Neher (1988). We calculated the time course of loading the NG108-15 cells using the following equation:

$$
\tau=(0.6 \pm 0.17) \cdot R_{\mathrm{A}} \cdot M^{1 / 3} t,
$$

where $\tau=$ seconds, $R_{\mathrm{A}}=\mathrm{M} \Omega$ access resistance of pipette, $M=$ daltons of diffusing substance). In our experiments, $R_{\mathrm{A}}$ was $0.5-1 \mathrm{M} \Omega$. Because this equation was derived for cells with a $7-8 \mu \mathrm{m}$ radius, we corrected the values of $\tau$ for cells with a radius of $20 \mu \mathrm{m}$. For antibodies, $\tau$ ranged between 3 and $12 \mathrm{~min}$. The transmitter responses were measured after 20 min of perfusion, which allowed the antibodies (the largest molecules used in the present work) to diffuse for at least a time corresponding to about twice the estimated $\tau$ for loading the cell. To eliminate the effect of variability among cells, we alternated experiments on cells perfused with active reagents with cells treated with control solutions. For calcium current measurements $\left(I_{\mathrm{Ca}, \mathrm{V}}\right)$, the extracellular solution contained (in $\mathrm{mM}$ ): $125 \mathrm{NaCl}, 5.4 \mathrm{CsCl}, 1.8 \mathrm{CaCl}_{2}, 1 \mathrm{MgCl}_{2}, 10 \mathrm{HEPES}, 5$ glucose, and 0.0005 tetrodotoxin, $\mathrm{pH} 7.4$ (with $\mathrm{NaOH}$ ). The use of $\mathrm{Ca}^{2+}$ as charge carrier accounts for the relatively fast rate of inactivation of $I_{\mathrm{Ca}, \mathrm{V}}$, compared with experiments in which $\mathrm{Ba}^{2+}$ was used (see Taussig et al., 1992). The pipette solution included (in $\mathrm{mm}$ ): $112 \mathrm{CsCl}, 1 \mathrm{MgCl}_{2}, 10$ EGTA, 30 HEPES, 3 ATP, and 0.1 GTP, pH 7.3 (with CsOH). For the measurement of the voltage-independent potassium current activated by BK $\left(I_{\mathrm{K}, \mathrm{BK}}\right)$ (Brown and Higashida, 1988), equimolar concentrations of $\mathrm{KCl}$ replaced $\mathrm{CsCl}$ in both extracellular and intracellular solutions, whereas EGTA was lowered to $0.1 \mathrm{~mm}$. All chemicals were obtained from Sigma (St. Louis, MO), except for nucleotides (Boehringer Mannheim, Indianapolis, IN). Transmitters (Peninsula, Belmont, CA) were used at $0.1 \mu \mathrm{M}$ and pipetted directly into the bath as described previously (WilkBlaszczak et al., 1994b). We consistently observed that prolonged dialysis per se did not significantly depress the responses to BK and Leu-Enk.

Voltage clamp. In several previous studies using appropriate combinations of voltage protocols, external channel blockers, and intrapipette $\mathrm{Ca}^{2+}$ buffers (Taussig et al., 1992; Wilk-Blaszczak et al., 1994b, 1996), we have determined that (1) differentiated NG108-15 cells express in approximately equal proportions both L-type (nifedipine-sensitive) and $\mathrm{N}$-type ( $\omega$-conotoxin GVIA-sensitive) $I_{\mathrm{Ca}, \mathrm{V}}$, along with modest levels of T-type (transient) $I_{\mathrm{Ca}, \mathrm{V}}$ (see also Caulfield et al., 1992); (2) with $1 \mathrm{~mm}$ intrapipette BAPTA, BK modulates both the N- and the L-type $I_{\mathrm{Ca}, \mathrm{V}}$, using three parallel G-protein pathways, which used $\mathrm{G}_{13}, \mathrm{G}_{\mathrm{q} / 11}$, and a pertussis toxin-sensitive G-protein (presumably $\mathrm{G}_{\mathrm{i} 2}$ ); (3) with $10 \mathrm{~mm}$ EGTA or $10 \mathrm{~mm}$ BAPTA in the pipette solution, BK modulates exclusively the N-type component of $\mathrm{I}_{\mathrm{Ca}, \mathrm{V}}$ via activation of one G-protein, $\mathrm{G}_{13}$ (we observed also that the response to BK is smaller in high $\mathrm{Ca}^{2+}$ buffers than in low $\mathrm{Ca}^{2+}$ buffers). Because in the present study, the cells were perfused with $10 \mathrm{mM}$ EGTA, the $\mathrm{G}_{\mathrm{q} / 11^{-}}$and $\mathrm{G}_{\mathrm{i} 2}$-regulated $I_{\mathrm{Ca}, \mathrm{V}}$ inhibitory pathways were suppressed, thus isolating the $\mathrm{G}_{13}$-mediated pathway that inhibits the N-type component of $I_{\mathrm{Ca}, \mathrm{V}}$ only.

In most experiments, the $I_{\mathrm{Ca}, \mathrm{V}}$ was activated by delivering square voltage-clamp step commands $(0 \mathrm{mV}, 100 \mathrm{msec})$ every $10 \mathrm{sec}$ from a holding potential of $-90 \mathrm{mV}$. To ensure that the $I_{\mathrm{Ca}, \mathrm{V}}$ was properly isolated and clamped, we used the following criteria. (1) Only cells of medium size ( $20 \mu \mathrm{m}$ radius) and with modest axonal outgrowth were used in the experiments. (2) The exchanges of $\mathrm{Cs}^{+}$and $\mathrm{K}^{+}$were completed rapidly after gaining access to the cell's interior $(<30 \mathrm{sec}$, based on the rapid and complete suppression of the outward current at the end of the depolarizing step command). (3) The access resistance did not increase during the perfusion time (20 min), as evinced by monitoring the analog subtraction of the capacitance (see below). Complete ionic exchange in cells perfused with $\mathrm{Cs}^{+}$using low-resistance pipettes $(0.5-1 \mathrm{M} \Omega$ ) was also supported by our previous observation that after combined application of nifedipine and $\omega$-conotoxin GVIA, BK did not elicit any significant shift of the residual current (Wilk-Blaszczak et al., 1994b). This latter observation strongly suggested that both the $I_{\mathrm{K}, \mathrm{BK}}$ and the $\mathrm{K}^{+} \mathrm{M}$ current (which are both modulated by BK in normal ionic conditions) (Brown and Higashida, 1988) were suppressed effectively by millimolar $\mathrm{Cs}^{+}$. (4) We have taken steps to minimize the additional capacitance introduced by the intrapipette perfusion system [these included holding the reservoir of the test solution (Fig. 1, inset) in a block of styrofoam, keeping metal parts as far away from the perfusion apparatus as possible and keeping the bath level low; see Tang et al., 1990].

The currents evoked by each step command, after partial analog correction of the capacitive current, were digitized at $10 \mathrm{kHz}$ and acquired using a Labmaster interface/IBM-compatible PC running pCLAMP software (Axon Instruments, Foster City, CA). The acquisition protocol executed simultaneous subtractions of the leakage and residual capacitive currents, using a $\mathrm{P} / 4$ protocol. For each cell, maximal inhibition of $I_{\mathrm{Ca}, \mathrm{V}}$ by the transmitters was measured as the percentage of peak current inhibited by the transmitter. Only $I_{\mathrm{Ca}, \mathrm{V}}$ measurements that did not display a run-down of the peak $I_{\mathrm{Ca}, \mathrm{V}}$ over the duration of the experiment were used. For each cell, the observations (for example, that $\mathrm{BK}$ produced inhibition of $I_{\mathrm{Ca}, \mathrm{V}}$ or that a certain treatment blocked inhibition of $I_{\mathrm{Ca}, \mathrm{V}}$ by $\mathrm{BK}$ ) were validated by confirming that the same effect was also present in the raw current before leakage and capacitance subtractions. This was obtained by monitoring simultaneously 
for the duration of the experiment both the raw and the subtracted traces. Only cells with small and stable leakage were used for the experiment.

Analysis of voltage-clamp data. The responses to BK were not normally distributed and were displayed as cumulative distributions of groups of data (McGehee et al., 1992; Wilk-Blaszczak et al., 1994a,b), a method that provides direct information about the scattering of the measurements. For the purpose of immediate comparison, response indices (equal to the areas under each distribution) were used. We observed, much like findings in our previous work on the $G_{13}$ pathway (WilkBlaszczak et al., 1994b), that agents that block this pathway (such as anti-G-protein antibodies) act in part by increasing the number of cells that do not respond to BK. For statistical purposes, we also counted as nonresponders cells with an occasional "run-up" coincident with the application of BK. We used the Fisher Exact Probability Test (one-tailed) for the comparison between groups of data. Responses to Leu-Enk were presented as mean percentage inhibitions \pm SDs.

Biochemistry and molecular biology. Immunoblot analysis was performed as described previously (Wilk-Blaszczak et al., 1994b). Affinitypurified polyclonal antibodies were obtained from Santa Cruz Biotechnology (Santa Cruz, CA), except for the anti-Rac2 (directed against Rac2 with an N-terminal hexahistidine tag). The specificity of anti Rac1, Cdc42, and Rho-A antibodies was validated by their ability to recognize the appropriate protein and by lack of cross-reactivity with other proteins. In the electrophysiological experiments, the antibodies were used at the final concentration of $0.8 \mu \mathrm{M}$.

The mRNA from NG108-15 cells was obtained using the guanidinium thiocyanate procedure, followed by oligo dT cellulose chromatography. For the RT-PCR technique, primers from the sequence of murine Rac1 were used (Moll et al., 1991). The sense primer was CAGTGAATCTGGGCCTATGGG (289-309); the antisense primer was ATGGCCAGCCCCTGCGGGTAG (574-554). The 287 bp product was subcloned using the TA cloning method, and its sequence was determined by doublestranded sequencing.

Recombinant Rho-GDI was expressed in Escherichia coli as a glutathione S-transferase (GST) fusion protein, and recombinant GST was produced in Spodoptera frugiperda cells with a baculovirus expression system. Both proteins were purified by chromatography through glutathione-Sepharose using standard procedures, dialyzed into the pipette solution (see above) without EGTA and stored in concentrated aliquots at $-80^{\circ} \mathrm{C}$. Each aliquot was diluted 10 -fold with the pipette solution before use.

The peptides used correspond to sequences (see Fig. $3 A$, inset) near the C termini of Rac1 (a.a. 178-188), Rac2 (a.a. 178-188), Cdc42 (a.a. 178-188), and RhoA (a.a. 180-190), and were synthesized and purified $(>95 \%)$ by Bio-Synthesis (Lewisville, TX). In the experiments using perfusion of anti-Rac1, anti-Cdc42, and anti-RhoA antibodies, the cells were treated with azide-free antibodies $(0.8 \mu \mathrm{M}$, Santa Cruz Biotechnology) for $20 \mathrm{~min}$.

\section{RESULTS}

\section{Rho-GDI attenuates the response to BK}

To determine whether Rho family proteins are involved in the responses to BK and Leu-Enk, we applied recombinant Rho-GDI intracellularly. Rho-GDI selectively binds to and inhibits guanine nucleotide exchange on monomeric G-proteins of the Rho family (Boguski and McCormick, 1993), thereby blocking interactions with downstream effectors. At the end of the application, the inhibition of $I_{\mathrm{Ca}, \mathrm{V}}$ by BK was examined first. The inhibition by Leu-Enk was measured thereafter as a control. After application of Rho-GDI, the inhibition of $I_{\mathrm{Ca}, \mathrm{V}}$ produced by $\mathrm{BK}$ was attenuated (Fig. $1 A_{1}, A_{2}$ ). A summary of the effects of Rho-GDI on the response to $\mathrm{BK}$ is presented in Figure $1 B$, which shows cumulative distributions $\left(B_{1}\right)$ and response indices $\left(B_{2}\right)$. In contrast, after application of Rho-GDI, inhibition of $I_{\mathrm{Ca}, \mathrm{V}}$ produced by Leu-Enk was retained (cells treated with Rho-GDI, $n=20$, $27 \pm 18 \%$; control cells, $n=14,22 \pm 12 \%$ ). The blocking action of Rho-GDI on the response to BK was incomplete; one explanation is that availability of endogenous Rho-GDI is already high, as evinced by immunodetection. Incomplete inhibitory effects of excess Rho-GDI were observed previously (Lamaze et al., 1996).

\section{Rac1}

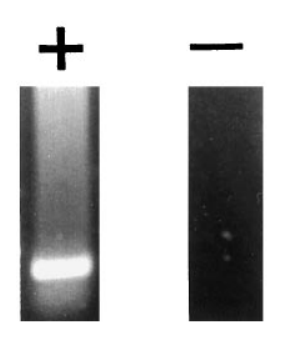

M C Std

\section{Rho-A}

\section{C Std}

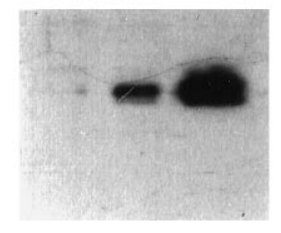

Cdc42

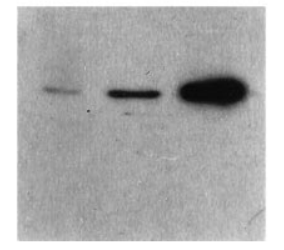

Rho-GDI

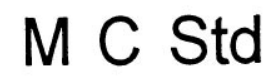

Figure 2. Detection of small G-proteins in NG108-15 by RT-PCR and immunoblotting. The top left panel (Rac1) shows RT-PCR assay of NG108-15 cells with $(+)$ and without $(-)$ cDNA synthesis. In each of the panels labeled $C d c 42$, Rho- $A$, and Rho-GDI, the left, middle, and right lanes contain, respectively, the resolved proteins from membranes $(M)$ and cytosol $(C)$ of NG108-15 cells and purified standard proteins $(S t d)$. The type of antibody used in each panel is indicated on top of each panel. Membranes (25 $\mu \mathrm{g}$ of protein; $M$ ) and cytosol (25 $\mu \mathrm{g}$ of protein; $C$ ) derived from differentiated NG108-15 cells, as well as standard proteins $(50$ ng of purified Cdc42, RhoA, and Rho-GDI; Std), were separated by SDS-PAGE, transferred to nitrocellulose, and analyzed by immunoblotting with affinity-purified antibodies $(0.2 \mu \mathrm{g} / \mathrm{ml})$. Rho family proteins and Rho-GDI used as standards were expressed and purified as GST fusion proteins, as described (Ridley et al., 1992), and cleaved with thrombin.

In some experiments $(n=14)$, GST-Rho-GDI was used. In other experiments $(n=7)$, Rho-GDI was used after proteolytically cleaving GST-Rho-GDI with thrombin and removing the free GST by glutathione-Sepharose chromatography. The two preparations provided identical results. In control experiments, pipette solution was applied alone intracellularly $(n=8)$ or together with GST $(n=7)$. No significant direct effects of these proteins on peak $I_{\mathrm{Ca}, \mathrm{V}}$ or holding current were observed. This effect of RhoGDI suggests that a member of the Rho family of small G-proteins is involved in the inhibition of $I_{\mathrm{Ca}, \mathrm{V}}$ by BK.

\section{Rho family members are expressed in NG108-15 cells}

Immunoblot analysis and RT-PCR were used to determine which members of the Rho family of small G-proteins are expressed in NG108-15 cells. Polyclonal antibodies against RhoA and Cdc42 detected proteins of the expected size in fractions of both membranes and cytosol from NG108-15 cells (Fig. 2). In contrast, polyclonal antibodies against Rac1 and Rac2, two monomeric G-proteins closely related to each other and to $\mathrm{Cdc} 42$, failed to identify appropriate polypeptides in NG108-15, although they robustly recognized the appropriate recombinant standard (data not shown). Because Rac2 is specific for myeloid cells, its detection was not expected in NG108-15 cells. However, Rac1 is expressed ubiquitously (Hall, 1994; Nobes and Hall, 1994; Mackay et al., 1995; Vojtek and Cooper, 1995; Ridley, 1996). To test 
$\mathrm{A}_{1}$

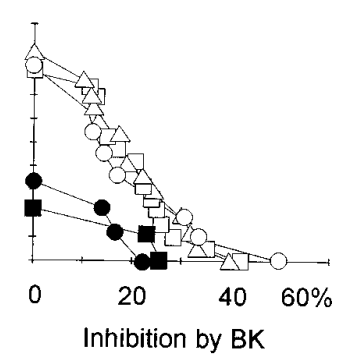

$\mathrm{A}_{2}$

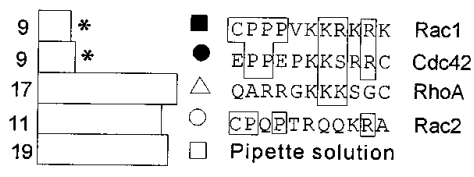

Response Index

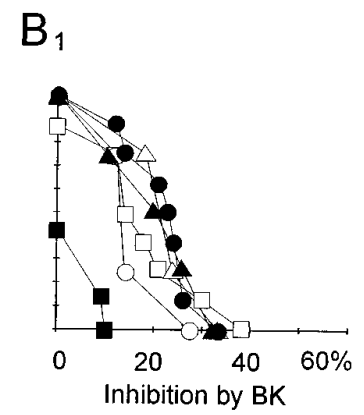

$\mathrm{B}_{2}$

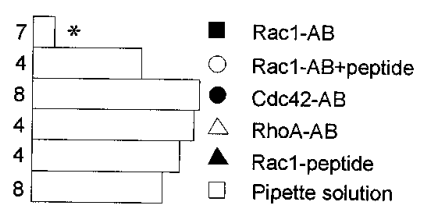

Response Index

Figure 3. Rac1 and/or Cdc42 mediate inhibition of $I_{\mathrm{Ca}, \mathrm{V}}$ by BK. $A_{1}, A_{2}$, Summary of the responses to BK $(0.1 \mu \mathrm{M})$ after intracellular perfusion with the indicated C-terminal peptides $(250 \mu \mathrm{M})$ or with pipette solution. The inset on the right displays the sequences of the peptides used. The cumulative distributions are shown in $A_{1}$, whereas $A_{2}$ displays the corresponding response indices. $B_{1}, B_{2}$, Summary of the responses to BK $(0.1$ $\mu \mathrm{M})$ after intracellular perfusion with the indicated antibodies $(0.8 \mu \mathrm{M}$; $A B)$ or with Rac1 antigenic peptide $(8 \mu \mathrm{M}$; solid triangles $)$ or pipette solution (open squares). Rac1 antigenic peptide was incubated on ice with anti-Rac1 antibody for at least $30 \mathrm{~min}$ before perfusion (open circles). Other explanations are as in Figure $1 B$.

whether Rac1 is expressed in NG108-15 cells, we used the RTPCR technique. Primers to the nonconserved regions of the mouse sequence were chosen to amplify the specific cDNA target sequence, generating a single product of the appropriate size (Fig. 2). The sequence obtained was identical to that of murine Rac1. The lack of detection of Rac1 by immunoblot analysis combined with positive detection by PCR suggests that Rac1 is a protein of low abundance (see also Stromstedt et al., 1994; Du et al., 1996; Tian et al., 1996). In conclusion, the evidence of expression of Rac1, Cdc42, and RhoA, along with the observed action of RhoGDI, suggested that these monomeric G-proteins may be involved in the calcium current-inhibitory pathway of BK.

\section{C-terminal peptides from Rho family members block the response to $\mathrm{BK}$}

To determine whether any of these monomeric G-proteins are involved in the inhibitory response to BK, we intracellularly applied synthetic peptides corresponding to the C-terminal region of Rac1, Rac2, Cdc42, and RhoA (Yeramian et al., 1987; Didsbury et al., 1989; Shinjo et al., 1990). Amino acid sequence homology among the Rho family proteins is least conserved within their C-terminal regions, which are thought to play key roles in interactions with effector and/or regulatory proteins. Based on these properties, synthetic peptides corresponding to Rac1 and Rac2 were used previously to demonstrate that Rac1 participates in activation and assembly of respiratory burst oxidase (Kreck et al., 1994). After application of either Rac1 or Cdc42 peptides, the

inhibition of $I_{\mathrm{Ca}, \mathrm{V}}$ by BK was blocked (Fig. $3 A_{1}, A_{2}$ ). In contrast, application of the Rac2 or RhoA peptides, as well as control pipette solution, under identical conditions, did not depress the response to BK. Importantly, none of the peptides significantly affected the response to Leu-Enk, measured in each cell after the response to $\mathrm{BK}$ ( $\mathrm{Rac} 1$ peptide treatment, $n=9$ cells, $27 \pm 18 \%$ inhibition; Cdc42 peptide, $n=9,39 \pm 18 \%$; RhoA peptide, $n=$ $15,21 \pm 7 \%$; Rac2 peptide, $n=12,31 \pm 14$; pipette solution, $n=$ $16,32 \pm 16 \%)$. These findings suggest that Rac1 and the closely related Cdc42 are potentially involved in the inhibition of $I_{\mathrm{Ca}, \mathrm{V}}$ by BK. None of the peptides used produced direct inhibitory effects on peak $I_{\mathrm{Ca}, \mathrm{V}}$ or holding current.

\section{The anti-Rac1 antibody blocks the response to BK}

To further test whether Rac1 and $\mathrm{Cdc} 42$ are involved in the response to $\mathrm{BK}$, we intracellularly applied polyclonal antibodies directed against the C-terminal regions of each of these proteins. Previously, anti-Rac1, anti-Rac2, and anti-Cdc42 blocking antibodies identical to those used in these studies were used to demonstrate the involvement of Rac2 in the regulation of oxygen radical production in phagocytes (Knaus et al., 1991). These same antibodies recognized appropriate recombinant proteins in immunoblot analysis (see above). Using the intracellular perfusion method, we have found that the application of an anti-Rac1 antibody blocked the response to $\mathrm{BK}$ (Fig. $3 B_{1}, B_{2}$ ). If the same antibody was preincubated with the antigenic peptide, the response to $\mathrm{BK}$ was retained (Fig. $3 B_{1}, B_{2}$ ). The antigenic peptide alone did not affect the response to BK $(8 \mu \mathrm{M})$ (Fig. $\left.3 B_{1}, B_{2}\right)$. In contrast to the action of the anti-Rac1 antibody, anti-Cdc42 and anti-RhoA antibodies did not block inhibition of $I_{\mathrm{Ca}, \mathrm{V}}$ by BK (Fig. $\left.3 B_{1}, B_{2}\right)$, although they recognized appropriate recombinant standards by immunoblot analysis (Fig. 2). We have also found that none of the treatments with antibodies significantly affected the response to Leu-Enk, measured in each cell after the response to BK (Rac1 antibody treatment, $n=6$ cells, $25 \pm 7 \%$ inhibition; peptide-blocked Rac1 antibody, $n=4,18 \pm 5 \%$; Cdc42 antibody, $n=9,36 \pm 13 \%$; RhoA antibody, $n=4,30 \pm 12 \%$; Rac1 peptide alone, $n=3,41 \pm 4$; pipette solution, $n=8,29 \pm 11 \%$ ).

BK and Leu-Enk both inhibit the same component of $I_{\mathrm{Ca}, \mathrm{V}}$ (Taussig et al., 1992; Wilk-Blaszczak et al., 1994b), but only the response to BK is blocked by the anti-Rac1 antibody. Therefore, it is unlikely that the effect of the antibody is attributable to direct suppression of $I_{\mathrm{Ca}, \mathrm{V}}$. We confirmed this idea by studying the effect of anti-Rac1 antibody on peak $I_{\mathrm{Ca}, \mathrm{V}}$ over a broad range of membrane potentials (Fig. $4 \mathrm{~A}$ ). As a control, current-voltage curves were obtained after perfusion of pipette solution. In cells treated with antibody (Fig. $\left.4 A_{2}\right)(n=2)$, the current-voltage relation was not altered significantly compared with one control cell (Fig. $4 A_{1}$ ), whereas the inhibition by BK was suppressed over the entire range of membrane potentials examined. Finally, the lack of any direct action of the anti-Rac1 antibody on $I_{\mathrm{Ca}, \mathrm{V}}$ was confirmed further by monitoring the peak $I_{\mathrm{Ca}, \mathrm{V}}$ for the duration of the experiment (Fig. $4 B)(n=7)$.

The specificity of the anti-Rac1 antibody for the $\mathrm{G}_{13}$ pathway was tested additionally by examining whether this antibody blocks a second response to $\mathrm{BK}$, activation of $I_{\mathrm{K}, \mathrm{BK}}$ (Brown and $\mathrm{Hi}$ gashida, 1988). This response is mediated by a distinct heterotrimeric G-protein, $\mathrm{G}_{\mathrm{q} / 11}$ (Wilk-Blaszczak et al., 1994a). $I_{\mathrm{K}, \mathrm{BK}}$ was measured in cells perfused with either antibody or pipette solution (Fig. $5 \mathrm{~A}_{1}, A_{2}$ ). We observed that the anti-Rac1 antibody did not significantly reduce the activation of $I_{\mathrm{K}, \mathrm{BK}}$ by BK (Fig. $5 B_{1}, B_{2}$ ). 

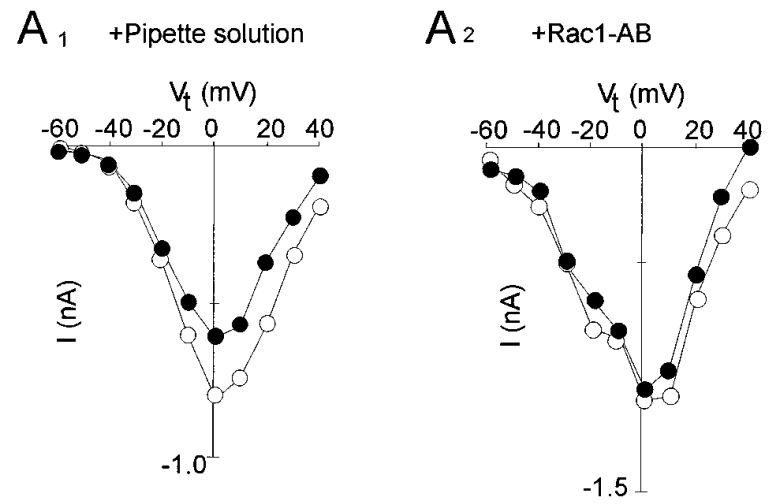

B

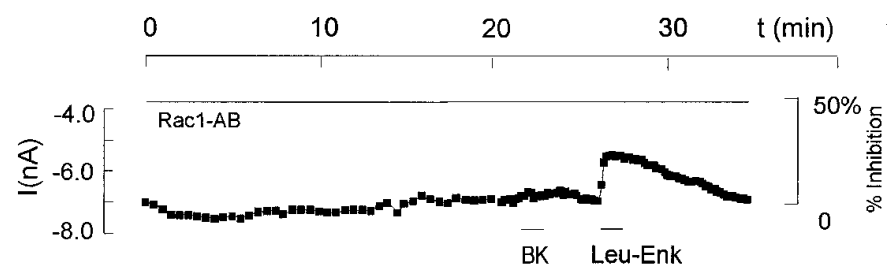

Figure 4. Action of the anti-Rac1 antibody over a broad range of membrane potentials and for the entire duration of the experiment. $A$, The two panels show peak $I_{\mathrm{Ca}, \mathrm{V}}$-voltage relations in two cells $\left(A_{1}, A_{2}\right)$ before (open circles) and during (closed circles) application of BK $(0.1 \mu \mathrm{M})$ after intracellular perfusion of either pipette solution $\left(A_{1}\right)$ or anti-Rac1 antibody $\left(0.8 \mu \mathrm{M} ; A_{2}\right)$. To capture the inherently transient response to $\mathrm{BK}$, the current-voltage curves were obtained using a series of short $(50 \mathrm{msec})$ commands $\left(V_{\mathrm{t}}\right)$ of increasing size at brief $(5 \mathrm{sec})$ intervals. $B$, Time course of the peak $I_{\mathrm{Ca}, \mathrm{V}}$ during perfusion with anti-Rac1 antibody $(0.8 \mu \mathrm{M})$ and application of BK and Leu-Enk $(0.1 \mu \mathrm{M})$. Between 0 and $20 \mathrm{~min}, I_{\mathrm{Ca}, \mathrm{V}}$ was activated every $30 \mathrm{sec}$, and in the remaining portion of the time course, every $10 \mathrm{sec}$. Data were acquired at $10 \mathrm{kHz}$.

\section{DISCUSSION}

We have presented converging lines of evidence showing that activation of the monomeric G-protein Rac1 is required for the inhibitory action of $\mathrm{BK}$ on $I_{\mathrm{Ca}, \mathrm{V}}$ (Fig. $5 C$ ). This conclusion is supported by the observation that Rac1 is expressed in NG108-15 cells and that intracellularly applied anti-Rac1 antibody blocks the response to $\mathrm{BK}$, and it is consistent with the effects of intracellularly perfused Rho-GDI and Rac1 peptide on the same response. We have studied in detail the action of the anti-Rac1 antibody on the inhibitory pathway of BK on $I_{\mathrm{Ca}, \mathrm{V}}$ and have observed that (1) the antibody effect is blocked by preincubation with the antigenic peptide, (2) it is not reproduced by any other antibodies used, and (3) it does not extend to the activation of $I_{\mathrm{K}, \mathrm{BK}}$ by BK or to the inhibition of $I_{\mathrm{Ca}, \mathrm{V}}$ by Leu-Enk. Low levels of expression of Rac1, as evinced by immunoblot analysis, might have rendered the blocking action of the perfused antibody more effective.

The involvement of $\mathrm{Cdc} 42$ in the inhibitory pathway of $\mathrm{BK}$ is not clear, because the inhibition of $I_{\mathrm{Ca}, \mathrm{V}}$ by BK is blocked by the $\mathrm{Cdc} 42$ peptide, but not by the anti-Cdc42 antibody. It is possible that the antibody might not have achieved during perfusion a sufficient concentration in the cells to block the response of Cdc42, which appears to be more abundant than Rac1 in NG108-15 cells. If both Rac1 and Cdc42 are required for the response to $\mathrm{BK}$, they may operate in a cascade, as shown previously in other systems (Chant and Stowers, 1995). Alternatively,
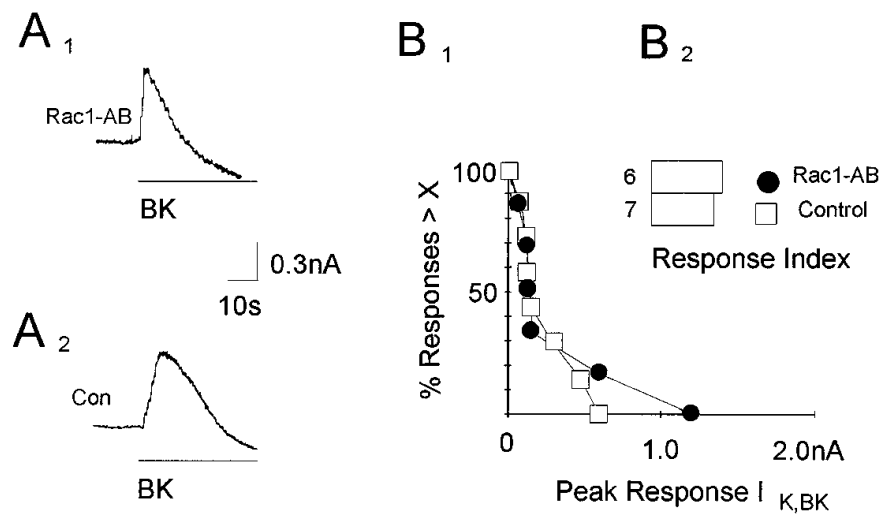

C

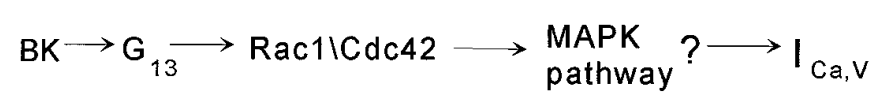

Figure 5. Anti-Rac1 antibody does not block a second effect of BK, activation of $I_{\mathrm{K}, \mathrm{BK}} \cdot A_{1}, A_{2}$, Examples of the activation of $I_{\mathrm{K}, \mathrm{BK}}$ by BK $(0.1$ $\mu \mathrm{M})$ obtained from two cells, after intrapipette perfusion with anti-Rac1 antibody $\left(A_{1}\right)$ or pipette solution $\left(A_{2}\right)$. Data were acquired at $100 \mathrm{~Hz} . B_{1}$, $B_{2}$, Summary of the $I_{\mathrm{K}, \mathrm{BK}}$ responses to BK $(0.1 \mu \mathrm{M})$ using cumulative distributions $\left(B_{1}\right)$ and response indices $\left(B_{2}\right)$. $C$, Proposed pathway for the inhibition of $I_{\mathrm{Ca}, \mathrm{V}}$ by BK. Other explanations are as in Figure $1 B$.

Cdc42 might not contribute to the response to BK in NG108-15 cells, and the blocking effect of the $\mathrm{Cdc} 42$ peptide on this response could be explained by its close sequence homology with the Rac1 peptide.

Although RhoA can couple to $\mathrm{G}_{13}$ (Buhl et al., 1995; Hooley et al., 1996) and is readily immunodetected in NG108-15 cells, the lack of effects of both the RhoA peptide and the anti-RhoA antibody makes it unlikely that this protein plays a role in the inhibition of $I_{\mathrm{Ca}, \mathrm{V}}$ by $\mathrm{BK}$. Consistent with this idea, BK (in contrast to thrombin or lysophosphatidic acid) does not induce RhoA-dependent neurite retraction in NG108-15 cells (Moolenar, 1995).

Monomeric G-proteins of the Rho family are involved in a broad range of cellular functions, including regulation of cell shape and motility, vesicle trafficking, and transmembrane transport (Hall, 1994; Nobes and Hall, 1994; Buhl et al., 1995; Mackay et al., 1995; Ridley, 1995, 1996; Vojtek and Cooper, 1995; Collins et al., 1996; Hooley et al., 1996; Lamaze et al., 1996; Machesky and Hall, 1996). The present work demonstrates that Rac1 and possibly $\mathrm{Cdc} 42$ are required for the inhibition of neuronal $I_{\mathrm{Ca}, \mathrm{V}}$ by $\mathrm{BK}$ and, as a consequence, for regulation of excitability. Although the observed inhibitory actions of the $\mathrm{G}_{13}$-Rac1 pathway on the amplitude of $I_{\mathrm{Ca}, \mathrm{V}}$ are on average of moderate size, at presynaptic terminals they could have important physiological effects (attributable to the nonlinearity of the $\mathrm{Ca}^{2+}$-dependency of transmitter release) (see Kandel et al., 1991). Furthermore, by allowing higher frequencies of action potential generation in primary sensory neurons (see Bleakman et al., 1990), inhibition of $I_{\mathrm{Ca}, \mathrm{V}}$ may enhance the BK-induced pain sensation (Dray and Perkins, 1993).

Our results parallel those recently obtained in muscles of Drosophila larvae (Zhong, 1995), where Ras was shown to mediate synaptic responses to a neuropeptide. Interestingly, Ras may mediate facilitation of $I_{\mathrm{Ca}, \mathrm{V}}$ by unknown receptors in neuronal cells (Collin et al., 1990; Hescheler et al., 1991; Hahnel et al., 1992; Fitzgerald and 
Dolphin, 1995), not inhibition as with Rac1 and Cdc42 (present work). It will be of interest to test the hypothesis that Rac1/Cdc42 inhibits $I_{\mathrm{Ca}, \mathrm{V}}$ via activation of specific MAPK pathways (Coso et al., 1995; Minden et al., 1995; Prasad et al., 1995; Zhang et al., 1995), as well as to examine the generality of these mechanisms in the inhibition of $I_{\mathrm{Ca}, \mathrm{V}}$ by neurotransmitters.

\section{REFERENCES}

Bleakman D, Thayer SA, Glaum SR, Miller RJ (1990) Bradykinininduced modulation of calcium signals in rat dorsal root ganglion neurons in vitro. Mol Pharmacol 38:785-796.

Boguski MS, McCormick F (1993) Proteins regulating Ras and its relatives. Nature 366:643-653.

Bokoch GM (1996) Interplay between Ras-related and heterotrimeric GTP binding proteins: lifestyles of the BIG and little. FASEB J 10:1290-1295.

Bourne HR, Sanders DA, McCormick F (1990) The GTPase superfamily: a conserved switch for diverse cell functions. Nature 348:125-132.

Bourne HR, Sanders DA, McCormick F (1991) The GTPase superfamily: conserved structure and molecular mechanism. Nature 349:117-127.

Brown DA, Higashida H (1988) Membrane current responses of NG108-15 mouse neuroblastoma x rat glioma hybrid cells to bradykinin. J Physiol (Lond) 397:167-184.

Buhl AM, Johnson NL, Dhanasekaran N, Johnson GL (1995) G $\alpha_{12}$ and $\mathrm{G} \alpha_{13}$ stimulate Rho-dependent stress fiber formation and focal adhesion assembly. J Biol Chem 270:24631-24634.

Cano E, Mahadevan LC (1995) Parallel signal processing among mammalian MAPKs. Trends Biochem Sci 20:117-122.

Caulfield MP, Robbins J, Brown DA (1992) Neurotransmitters inhibit the $\omega$-conotoxin-sensitive component of Ca current in neuroblastoma $x$ glioma (NG108-15) cells, not the nifedipine-sensitive component. Pflügers Arch 420:486-492.

Chant J, Stowers L (1995) GTPase cascades choreographing cellular behavior: movement, morphogenesis, and more. Cell 81:1-4.

Cobb MH, Goldsmith EJ (1995) How MAP kinases are regulated. J Biol Chem 270:14843-14846.

Collin C, Papageorge AG, Lowy DR, Alkon DL (1990) Early enhancement of calcium currents by H-ras oncoproteins injected into Hermissenda neurons. Science 250:1743-1745.

Collins LR, Minden A, Karin M, Brown JH (1996) G $\alpha 12$ stimulates c-Jun NH2-terminal kinase through the small G proteins Ras and Rac. J Biol Chem 271:17349-17353.

Coso OA, Chiariello M, Yu J-C, Teramoto H, Crespo P, Xu N, Miki T, Gutkind JS (1995) The small GTP-binding proteins Rac1 and Cdc42 regulate the activity of the JNK/SAPK signaling pathway. Cell 81:1137-1146.

Didsbury J, Weber RF, Bokoch GM, Evans T, Snyderman R (1989) rac, a novel ras-related family of proteins that are botulinum toxin substrates. J Biol Chem 264:16378-16382.

Dray A, Perkins M (1993) Bradykinin and inflammatory pain. Trends Neurosci 16:99-104.

Du X, Everett ET, Wang G, Lee WH, Yang Z, Williams DA (1996) Murine interleukin-11 (IL-11) is expressed at high levels in the hippocampus and expression is developmentally regulated in testis. J Cell Physiol 168:362-372.

Fitzgerald EM, Dolphin AC (1995) P21-ras is involved in regulation of voltage-dependent calcium channels in cultured rat dorsal root ganglion cells. Biochem Soc Trans 23:193S.

Hahnel C, Gottmann K, Wittinghofer A, Lux H-D (1992) p21 ras oncogene protein selectively increases low-voltage-activated $\mathrm{Ca}^{2+}$ current density in embryonic chick dorsal root ganglion neurons. Eur J Neurosci 4:361-368.

Hall A (1994) Small GTP-binding proteins and the regulation of the actin cytoskeleton. Annu Rev Cell Biol 10:31-54.

Hamill OP, Marty A, Neher E, Sakmann B, Sigworth FJ (1981) Improved patch-clamp techniques for high-resolution current recording from cells and cell-free membrane patches. Pflügers Arch 3911:85-100.

Hamm HE, Gilchrist A (1996) Heterotrimeric G proteins. Curr Opin Cell Biol 8:189-196.

Hamprecht B, Glaser T, Reiser G, Bayer E, Propst F (1985) Culture and characteristics of hormone-responsive neuroblastoma $\mathrm{x}$ glioma hybrid cells. Methods Enzymol 109:316-347.

Hepler JR, Gilman AG (1992) G proteins. Trends Biochem Sci 17:383-387.
Hescheler J, Schultz G (1993) G-proteins involved in the calcium channel signalling system. Curr Opin Neurobiol 3:360-367.

Hescheler J, Rosenthal W, Trautwein W, Schultz G (1987) The GTPbinding protein, $G_{o}$, regulates neuronal calcium channels. Nature 325:445-447.

Hescheler J, Klinz F-J, Schultz G, Wittinghofer A (1991) Ras proteins activate calcium channels in neuronal cells. Cell Signal 3:127-133.

Hille B (1992) G protein-coupled mechanisms and nervous signaling. Neuron 987:187-195.

Hille B (1994) Modulation of ion-channel function by G-protein-coupled receptors. Trends Neurosci 17:531-536.

Hofmann F, Biel M, Flockerzi V (1994) Molecular basis for $\mathrm{Ca}^{2+}$ channel diversity. Annu Rev Neurosci 17:399-418.

Hooley R, Yu C-Y, Symons M, Barber DL (1996) G $\alpha 13$ stimulates $\mathrm{Na}^{+}-\mathrm{H}^{+}$exchange through distinct Cdc42-dependent and RhoAdependent pathways. J Biol Chem 271:6152-6158.

Hunter T (1995) Protein kinases and phosphatases: the yin and yang of protein phosphorylation and signaling. Cell 80:225-236.

Kandel ER, Schwartz JH, Jessel TM (1991) Principles of neural science, Ed 3. New York: Elsevier.

Knaus UG, Heyworth PG, Evans T, Curnutte JT, Bokoch GM (1991) Regulation of phagocyte oxygen radical production by the GTP-binding protein Rac 2. Science 254:1512-1515.

Kreck ML, Uhlinger DJ, Tyagi SR, Inge KL, Lambeth JD (1994) Participation of the small molecular weight GTP-binding protein Rac1 in cell-free activation and assembly of the respiratory burst oxidase. J Biol Chem 269:4161-4168.

Kyriakis JM, Avruch J (1996) Sounding the alarm: protein kinase cascades activated by stress and inflammation. J Biol Chem 271:24313-24316.

Lamaze C, Chuang TH, Terlecky LJ, Bokoch GM, Schmid SL (1996) Regulation of receptor-mediated endocytosis by Rho and Rac. Nature 382:177-179.

Machesky LM, Hall A (1996) Rho: a connection between membrane receptor signalling and the cytoskeleton. Trends Cell Biol 6:304-310.

Mackay DJG, Nobes CD, Hall A (1995) The Rho's progress: a potential role during neuritogenesis for the Rho family of GTPases. Trends Neurosci 18:496-501.

McGehee DS, Goy MF, Oxford GS (1992) Involvement of the nitric oxide-cyclic GMP pathway in the desensitization of bradykinin response of cultured rat sensory neurons. Neuron 9:315-324.

Minden A, Lin A, Claret F-X, Abo A, Karin M (1995) Selective activation of the JNK signaling cascade and c-Jun transcriptional activity by the small GTPases Rac and Cdc42Hs. Cell 81:1147-1157.

Moll J, Sangig G, Fattori E, Van der Putten H (1991) The murine racl gene: cDNA cloning, tissue distribution and regulated expression of rac1 mRNA by disassembly of actin microfilaments. Oncogene 6:863-866.

Moolenar WH (1995) Lysophosphatidic acid signalling. Curr Opin Cell Biol 7:203-210.

Neer EJ, Smith TF (1996) G protein heterodimers: new structures propel new questions. Cell 84:175-178.

Nobes C, Hall A (1994) Regulation and function of the Rho subfamily of small GTPases. Curr Opin Genet Dev 4:77-81.

Prasad MVVSV, Dermott JM, Heasley LE, Johnson GL, Dhanasekaran N (1995) Activation of Jun kinase/stress-activated protein kinase by GTPasedeficient mutants of $\mathrm{G} \alpha_{12}$ and $\mathrm{G} \alpha_{13}$. J Biol Chem 270:18655-18659.

Pusch M, Neher E (1988) Rates of diffusional exchange between small cells and a measuring patch pipette. Pflügers Arch 411:204-211.

Ridley AJ (1995) Rho-related proteins: actin cytoskeleton and cell cycle. Curr Opin Genet Dev 5:24-30.

Ridley AJ (1996) Rho: theme and variations. Curr Biol 6:1256-1264.

Ridley AJ, Paterson HF, Johnston CL, Diekman D, Hall A (1992) The small GTP-binding protein rac regulates growth factor-induced membrane ruffling. Cell 70:401-410.

Schmitt K, Däubener W, Bitter-Suermann D, Hadding U (1988) A safe and efficient method for elimination of cell culture mycoplasmas using ciprofloxacin. J Immunol Methods 109:17-25.

Shimahara T, Icard-Liepkalins C, Ohmori H, Shigemoto T (1990) Mobilization of intracellular $\mathrm{Ca}^{2+}$ and suppression of inward currents in a neuronal hybrid cell line triggered by bradykinin. Brain Res 524:219-224.

Shinjo K, Koland JG, Hart MJ, Narasimhan V, Johnson DI, Evans T, Cerione RA (1990) Molecular cloning of the gene for the human placental GTP-binding protein $G_{p}(G 25 K)$ : identification of this GTP- 
binding protein as the human homolog of the yeast cell-division-cycle protein CDC42. Proc Natl Acad Sci USA 87:9853-9857.

Stromstedt M, Warner M, Gustafsson JA (1994) Cytochrome P450 sec of the 4A subfamily in the brain. J Neurochem 63:671-676.

Tang JM, Wang J, Quandt FN, Eisenberg RS (1990) Perfusing pipettes. Pflügers Arch 416:347-350.

Taussig R, Sanchez S, Rifo M, Gilman AG, Belardetti F (1992) Inhibition of the $\omega$-conotoxin-sensitive calcium current by distinct $\mathrm{G}$ proteins. Neuron 8:799-809.

Tian YM, Urquidi V, Ashcroft SJ (1996) Protein kinase C in $\beta$ cells: expression of multiple isoforms and involvement in cholinergic stimulation of insulin secretion. Mol Cell Endocrinol 119:185-193.

Tsien RW, Ellinor PT, Horne WA (1991) Molecular diversity of voltagedependent $\mathrm{Ca}^{2+}$ channels. Trends Pharmacol 12:349-354.

Tsunoo A, Yoshii M, Narahashi T (1986) Block of calcium channels by enkephalin and somatostatin in neuroblastoma-glioma hybrid NG108-15 cells. Proc Natl Acad Sci USA 83:9832-9836.

Vojtek AB, Cooper JA (1995) Rho family members: activators of MAP kinase cascades. Cell 82:527-529.
Wilk-Blaszczak MA, Gutowski S, Sternweis PC, Belardetti F (1994a) Bradykinin modulates potassium and calcium currents in neuroblastoma hybrid cells via different pertussis toxin-insensitive pathways. Neuron 12:109-116.

Wilk-Blaszczak MA, Singer WD, Gutowski S, Sternweis PC, Belardetti F (1994b) The $G$ protein $G_{13}$ mediates inhibition of voltage-dependent calcium current by bradykinin. Neuron 13:1215-1224.

Wilk-Blaszczak MA, Singer WD, Belardetti F (1996) Three distinct G protein pathways mediate inhibition of neuronal calcium current by bradykinin. J Neurophysiol 76:3559-3562.

Yeramian P, Chardin P, Madaule P, Tavitian A (1987) Nucleotide sequence of human rho cDNA clone 12. Nucleic Acids Res 15:1869.

Zhang S, Han J, Sells MA, Chernoff J, Knaus UG, Ulevitch RJ, Bokoch GM (1995) Rho family GTPases regulate p38 mitogen-activated protein kinase through the downstream mediator Pak1. J Biol Chem 270:23934-23936.

Zhong Y (1995) Mediation of PACAP-like neuropeptide transmission by coactivation of Ras/Raf and cAMP signal transduction pathways in Drosophila. Nature 375:588-592. 